\title{
Practical Problems Of Managing Corporate Identity Of Capital Structures In Poland
}

\author{
Anna Zarębska, Technical University of Lublin, Poland
}

\begin{abstract}
The issue of managing corporate identity systems is currently widely discussed in the scientific literature. More and more often this knowledge is also put into practice in counselling projects within the field of integrated system of corporate identity. Far less space is devoted to this matter in the context of capital structures. In practice however, implementing coherent systems of corporate identity in case of capital structures causes more problems than in case of individual organizations. Capital structures are forms of organization which aim at reconciling two seemingly contrary objectives in modern economies: an increase resulting from globalization process and capital concentration, and expectation of flexibility, activity and capability of quick decision-making on the side of market participants. Their creation and functioning requires special or even unique competences resulting from the presence of many business entities in a group. Thus, there is a higher risk of making a mistake than in the case of managing an individual entity. The article concerns practical aspects of managing identity systems of capital structures in Poland and is the outcome of a few years of research over this issue.
\end{abstract}

Keywords: Capital structure, corporate identity management

\section{INTRODUCTION}

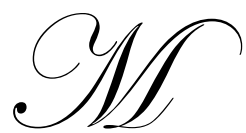

odern market environment may be characterised by the phrase "the age of knowledge" or "postindustrial economy". Company is characterised by its intangible assets (knowledge, information, brand, vision, reputation, corporate identity etc.), which are difficult to copy, unrepeatable and permanently distinguish the company on the market. This is of special importance now that an increasing number of market activity concentrates on the services and not on the production or farming.

This changing market reality makes companies abandon the classic ways of competing on the market or, at least, supplement them with new activities. Competitive prices and quality are no longer enough and there appears a need to look for different and new methods of gaining the competitive advantage. Intangible assets may be an answer to this. They significantly change the way companies do business, deal with their partners, design new products or build up the relations with their clients.

One of the intangible assets is corporate identity. This issue is widely discussed in literature and management guidebooks. Still, the issue of corporate identity system does not concern individual entities alone, but applies to capital structures as well, as in the fusion and takeover processes building a coherent identity of new corporate object is of great importance.

Before fusion (takeover) individual companies live their own lives. After it, they are something more than just a sum total of the people they employ, products or services which they create and other variables that may be defined such as mission, operation policy, strategy or structure, as additionally to these there appear synergy effects. In order to obtain these, and maintain them later, it is very important to care for an integrated corporate identity after the merger (takeover). 


\section{THE ESSENCE CORPORATE IDENTITY}

Among authors there is no agreement as to what corporate value is, or what are its components. On the one hand, the discussion runs over these areas of a company that are linked with the identity, on the other hand - over the theoretic and practical approach. The abovementioned attitudes are of one-sided character and they consider identity from the point of view of a broadly defined PR, idea or image, or they even misconceive corporate identity with corporate culture. Similarly, there is no agreement as to whether the identity is a certain (relatively) stable feature of an organization or rather a phenomenon, which has come into being and influenced the present. The number of issues of the topic in question makes corporate identity an ambiguous and difficult to capture concept.

The easiest way to define corporate identity is to say it is a system embracing all visual, verbal and behavioural announcements that the organisation sends to its internal and/or external environment, which express the values and beliefs the company follows in its every-day operations that aim at making company distinct from others as well as at building competitive advantage by taking specific place in consumers' minds. The abovementioned description of identity points out to the fact that every organisation possesses its own identity. Sometimes however, it may be incognizant or incoherent. Then, however, it may not be referred to as a strategic company's resource.

Modern look at corporate identity characterizes it as a phenomenon of hierarchical structure (Sitko, Zarębska, 2007; Zarębska, 2008; 2009). The phenomenon points out to the dynamic character of identity as well as to the fact that it can be subject to modifications in certain periods of time. It is thus important to see corporate identity as a process. In such a context there is a place for discussing corporate identity management.

On the other hand, hierarchical structure points out to independent levels, which make up corporate identity (Bernstein, 1992). The following levels are all considered to be part of corporate identity: level of environment, behaviours, competences, beliefs, values and the level of ideal identity which identifies the role the corporation plays in the environment and which comprises company's mission and vision.

\section{CAPITAL STRUCTURE IN POLISH MARKET REALITY}

Capital structure consists of legally independent business entities i.e. capital companies. The mutual relations between these entities result from ownership relations. This means that capital assignment arise from possessing shares or stocks by the subject that is superior to the inferior ones. The choice of a proper capital structure is surely not an easy task. It depends on the specificity and size of the business activity carried out. It always demands analysing the strong and weak points of running the activity in each of the structures and, as a consequence, assessing the effectiveness of each solution.

Creating capital structures aims at increasing company's effectiveness and efficiency and, as a result, increasing the value for shareholders. In its essence they meet the requirements of modern economy. On one hand they are the outcomes of globalisation processes, on the other - they enable to form an optimal size of structure's individual participant so as to provide flexibility, activeness and the possibility of quick decision-making that competitive market expects. First capital structures appeared as early as $19^{\text {th }}$ century in Belgium (1822), England (1886), Switzerland (1879), Germany (1871) and the USA (1870). The history of Polish capital structures, represented in the country as capital groups, is relatively short. A great majority of them was launched in the nineties of the $20^{\text {th }}$ century.

\section{FACTORS DETERMINING THE FORM OF CORPORATE IDENTITY IN CORPORATE STRUCTURE}

Managing corporate identity system of a capital structure consists in identifying factors that determine the shape of identity of such an entity in the first place. This is schematically shown in Figure 1.

In the first group of these factors a broadly understood historical conditioning of launching these organizations have to be considered. This particularly refers to the abovementioned processes of transforming national economy, which influenced the shape of the newly formed and the changes in the already existing business 
entities, as well as the activities these entities currently undertake in order to improve, maintain or increase effectiveness of their operations.

Another group of factors constitutes the external surrounding of the structure as well as of dominating subject and individual dependent companies, which is connected with assessing development perspectives of the activities the company runs ${ }^{1}$. At this point, it is important to notice that in Polish conditions macroeconomic factors have relatively greater influence on companies than on their counterparts in the stabilised market economies. Necessary changes in the infrastructure and sector, adaptation processes as well as lack of stable country policy have often lead to the situation where risk assessment of the company's main activity determines, to a great extend, its current situation and development plans.

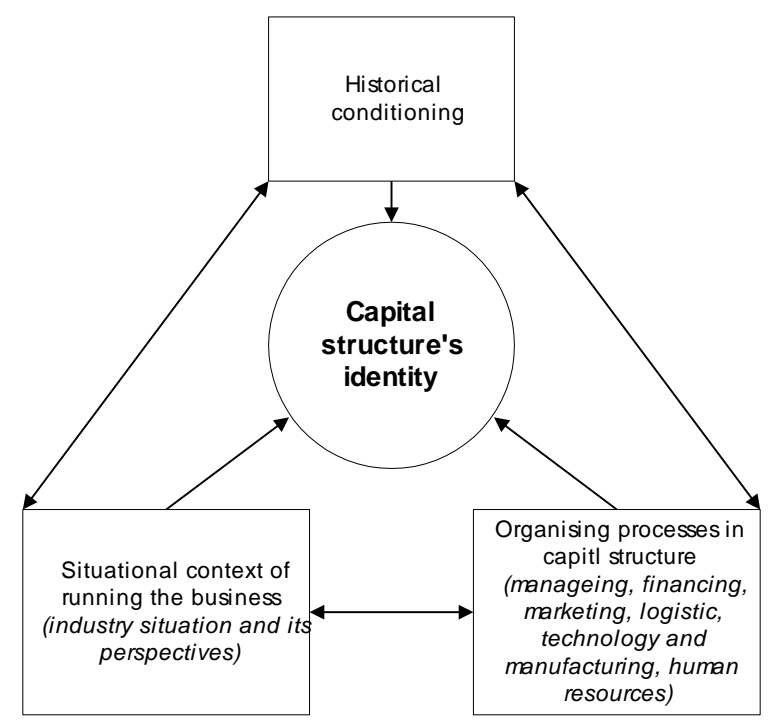

Figure 1: Factors Influencing the Shape of Identity in Polish Capital Structures Source: own work

The third group of factors concerns the internal aspect of capital structure and is connected with management organisation of such a multi-entity subject. In practice this comes down to effective usage of productiveness, efficient marketing activities, optimalisation of logistic, development and financing processes as well as human resources management. The way these areas are organised is, on one hand, of great importance to achieving competitive advantage and, on the other, it influences strongly the construction of capital structure identity, and as a consequence - the range of achievable synergy effects.

Summing up, the group of factors connected with historical conditioning is closely linked to the path of establishing a capital structure, situational context of running the activity depends on the level of industry attractiveness while process organisation in capital structure influences the general state of group organisation. All of these three factor groups determine to a great extend the process of forming group identity in Polish capital groups.

\footnotetext{
${ }^{1}$ The situation of the industry is of vital importance for the situation of companies functioning in it and in this case also of capital structures. This is acknowledged by the authors dealing with issues of strategic management See e.g Hax, Majluf (1991).
} 


\section{MANAGING CORPORATE IDENTITY SYSTEM OF CAPITAL STRUCTURES IN POLAND - PRACTICAL PROBLEMS}

Managing corporate identity system of capital structures consists mainly in the necessity of cultural integration of all the companies that belong to the capital structure. There exist a danger that instead of synergy effects there will appear effects of dyssynergy resulting from contrary values, norms and assumptions of the companies subject to merger. The complexity of the process of integration demands recognition and careful planning of all the actions in a well-thought-out and detailed manner so as to avoid possible disappointments when comparing with previously assumed results. Impromptus in this area may be particularly expensive. Also Hofstede explains this saying that corporate culture is a collective phenomenon shared by all the people who lived or live together in the same social community; it is a programmed way of thinking that is reflected by the behaviour of the community members - this forms the basis for distinction of one community from the others (Koźmiński, Piotrowski, 2007). It is important to refer the cultural patterns to the organisation itself, because it forms their foundations. It is then understandable that separating an organisation from culture is difficult and would probably be impossible (Sikorski, 2002). In this context cultural problems occurring in a consolidated company are natural and rarely avoidable.

Effective identity consolidation of companies requires precise identification of cultural levels in the companies that are subject to fusion, defining how different they are and planning actions that lead to eliminating cultural gap so that it was possible to form common assumptions, norms, values and artefacts in a merged organisation. If however, the changes proposed are contrary to the tradition of one of the companies for example, then their implementation will bring little or no effect. Effective organisational change does not include artefacts only, but it aims at changing the deeper levels of company's culture above all.

Masłyk-Musiał (2006) points out that the factors influencing the shape of corporate culture are in particular the leaders, and their behaviour, criteria used in making decision, reward system in the organisation, criteria of punishing and types of incentives, habits connected with the status, changing roles, personal recognition, loss of power, social facilities, technologies, corporate structure, systems and procedures as well as psychological side of designing working environment.

During the preparation of the process of consolidation changes it is important to take into account all the abovementioned factors, define corporate culture in each entity, check in which areas there occur the biggest differences (these areas will demand the most attention in the process of cultural consolidation) and to draw up a plan of the cultural changes that will lead to establishing a homogenous culture within the whole consolidated business entity.

As mentioned by Clarke (1997, pp. 120-128) for the process of changes in "hard" areas of companies consolidation to be most effective it must be followed by:

- $\quad$ creating corporate culture based on learning and enterprise - a common mistake of consolidated companies is that they become passive after the change has taken place;

- full commitment to company's affairs - readiness for consolidation changes often results from the conviction that there is no other alternative of action;

- $\quad$ vision, shared by all the workers, of the future, consolidated company - during the process of changes the vision of consolidated company should be created by the leader; this allows participants of the corporation - even in crisis situations and failures - to keep the dedication and continue struggling with the process of the changes. Therefore vision should constitute a common property - otherwise it will not be a real factor motivating to undertaking actions aiming at consolidation;

- determining the conditions that allow to maintain the changes on the desired level - flexibility in reaction and clear tasks description on individual posts aims at preventing duplicating the range of duties and responsibilities. It also leads to maintaining balance between management on the level of strategy and tactics; 
- $\quad$ a common diagnosis of problems of consolidated company - including the subordinates into company's problem-solving allows them to learn from their own mistakes but also influences their dedication to the process of changes;

- $\quad$ strengthening management style that favours people - people taking the risk of changes are those who feel confident about their own value and safety. Thus, the management of consolidating companies that are in the phase of changes (and also afterwards) should form premises for the managing style that awards success, favours achieving objectives and makes people satisfied with themselves and their company.

Corporate culture is of great importance in the processes of companies consolidation. If only it is proeffective, it facilitates carrying out the plans as well as maintaining implemented changes.

Determining the required cultural changes results from assessing how much the existing culture facilitates and how much it hinders conducting consolidation operation and how much it is shared and accepted by the organisation participants. It should also be borne in mind that the implemented culture - if it violates the established standard - may be difficult to introduce. Cultural risk assessment consists in determining the risk of error and the effects of potential negative consequences that accompany the change.

All the actions concerning the social aspect of companies integration process should be conducted with full participation of human resources department in the decision process. This concerns the participation of leaders (representatives) of HR department in the discussions of potential merger. The point is to award the issues of Human Resources with the appropriate importance from the very beginning and to point out the possible dangers for the effectiveness of the enterprise resulting from this. Usually, the people responsible for personal matters step in later (while working on matters of redundancies, remunerations and costs, collective agreement, retirement obligations, etc.). However, even if HR manager and the team leader will not take the decision of fusion, the sooner they are allowed in the process, the more effectively the problems that may occur in successive stages of the merger process can be solved. If these problems are ignored they may negatively influence business results. It is good to determine the cultural risk and cultural compatibility in the initial stage. This allows to avoid many problems resulting from the gap (e.g. in values, assumptions or ways of behaviour) in the future stages. This is a task HR department should perform. The knowledge about culture gathered in the process of due dilligence ${ }^{2}$ has a great influence on purchasing decisions, on the choice of optimal organizational form and on preparing an effective plan of integration.

Change management in the process of consolidation should above all aim at creating a common corporate identity of a newly-formed capital structure. The point is not only the cultural coherence but also a broader look on the issue of corporate identity.

This is a particularly difficult task as each of the entities has its own identity, so there is a visible distinction between organization and competition. This allows the costumers, suppliers and workers to recognize, understand and describe clearly corporate issues that occur in the organization. Opinions and sensations, feelings and dreams, hopes and expectations expressed by the employers, suppliers, clients, stakeholders, government as well as the whole society and mass media contribute to determining corporate identity. As a result, corporate identity presents the collage of experiences and expectations of a vast group of people, who see the organization from different perspectives (Hatch, Schultz, 2004, p.1).The identity of each company is a complex one. It concerns the effectiveness of its services and products, shares value, workers' ambition or public relations operations. The complexity of this phenomenon requires that it was especially thoroughly examined and recognized not only during the merger but also before it.

Three models connected with developing and managing capital structure identity can be distinguished (Filipek, 2000). The first one is monolithic identity. It assumes for the whole structure all the homogenous elements

\footnotetext{
${ }^{2}$ Due dilligence allows for assessing the risk connected with transaction referring to a particular company, as well as for the diagnosis of general situation in the industry. The scope of the research may be narrow e.g. only supervising the financial condition, or broad: legal state of environment protection, human resources, finances. Apart from that company's value can also be audited. The results of due dilligence facilitate the preparation of the company's takeover schedule as well as constructing final valuation of the company.
} 
of corporate identity paying particular attention on the symbolism. The benefits that result from accepting this model are the effect of scales and the clarity and coherence of the announcement the group presents. The other - extreme model - is the so-called brand identity. It is described by individual identity elements for each enterprise that make up the structure. In this case creating capital structure is only of capital character. A strong point of this model is the independent identity of each of the subjects, which allows for extension of the activity into different market segments. The third model is the so-called dependent (supporting) identity where only selected identity elements are common for the capital structure and companies that create it. This model allows to control freely the importance and strength of dependence of separate subjects from the parent company, which permits unhindered introduction of new companies to the structure.

In the context of the above deliberations building up corporate identity of capital structure according to the first model demands an integrated strategy in the field of creating and managing values in the newly formed business entity, homogenous visualisation system of the group and its consistent presentation on the market through a wide range of marketing actions with special attention being paid to public relations operations. It is also creating, supporting and developing uniform communication of capital structure with its environment and a careful planning operations in the field of a common human resources policy. In the second case (brand identity) building up corporate identity does not differ from building up identity of a single enterprise. In this strategy each organisation making up capital structure functions as a separate and independent company. In the third case, however, building up capital structure consists mainly in introducing a uniform system of visual identification with a simultaneous maintaining cultural autonomy of separate subjects. In this case the role of human resources department is not that important as in the first model.

Capital structure identity differentiates it from other business entities that function on the same market; moreover, as Caves and Porter claim (1977, p. 421-434), identity backs up the entrance barriers which hinder the enterprises that do not belong to the structure from functioning on the market areas that are the domain of operations of the capital structure and its participants. This advantage of capital structure should be stressed especially in the context of its identity.

Moreover Reger and Huff (1993, p. 103-123) point out that the process of creating capital structure identity is influenced by both - the micro- and macro- forces, which have affected the separate subjects dependent from capital structure. This is schematically shown in Figure 2.

The process of learning has a direct influence on the identity of capital structure on micro-scale both in the area of gaining the knowledge ${ }^{3}$ and also in the social sphere ${ }^{4}$. Whereas on a macro-scale identity is affected by different types of influences coming from other institutions and market participants, economic forces and historical impacts (Peteraf, Shanley, 1997, p. 172).

Social identity or social learning are micro scale processes, which are, however, determined by macrocontext. Macro-context not only allows for using strategic chances (Blau, 1994) but also is the basis for general norms and values identical for all the companies in the same lines of business or sector, which is defined by Abrahamson and Fombrum as a macro-culture.

A strong identity of capital structure allows an efficient accomplishing the strategy and achieving significant synergy effects within the capital group according to the real sense of forming such an organization (Hatten, Hatten, 1987, p. 329-342; Barney, Hoskisson, 1990, p. 187-198).

\footnotetext{
${ }^{3}$ The differences between the capabilities for learning of individual managers and the ability to gain knowledge by the whole capital group are described by e.g. Hatten, Hatten (1987, p.329-342).

${ }^{4}$ Processes of social learning are described broadly by e.g. Bandura (1986); Wood (2006); Spender (1989); Huff (1982, p. 119131); Ring, Van de Ven (1992, p. 483-498); Coleman (1990); Ashforth, Mael (1996, p. 19-64).
} 


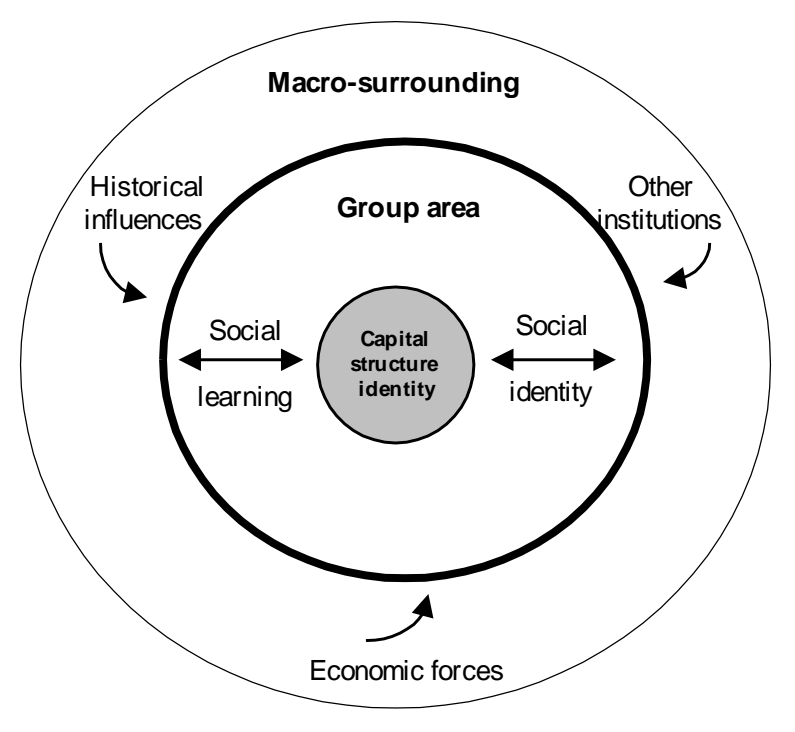

Figure 2: Forces that Form the Identity of A Capital Structure Source: Peteraf, Shanley (1997, p.167)

Communicational strategy plays a key role in implementing the changes and building a new system of corporate identity of capital structure. The main goal is providing conformity between communication and behaviours as well as assessing the programme of building up identity in accordance with the arrangements, irrespective of whether or not these targets are achieved. As pointed out by Wilczak (2004, p.40) the assessment aims at checking how the newly introduced identity system was perceived by the environment and whether and if yes, than to what degree, the organisation managed to achieve the planned alternation of the way it and its products are perceived.

\section{CONCLUSIONS}

To sum up, in the context of the whole capital structure building up an integrated system of identity requires a range of operations which concern the following issues:

- $\quad$ building up a coherent philosophy of actions for the entire capital structure,

- $\quad$ identifying fundamental values specific for separate subjects and creating a uniform system of values that are in effect in all the capital structure,

- creating a new corporate mission that supports the mission and achieving goals of separate subjects,

- $\quad$ establishing a common vision of a newly formed organisation,

- determining product range and services offered by the capital structure and their mutual promotion on the market,

- $\quad$ creating a new corporate structure of capital structure,

- $\quad$ establishing new standards of workers' behaviours as well as organisation as a whole in the context of newly formed group,

- $\quad$ developing a common human resources policy for the entire capital structure (integrating processes of planning, recruiting, motivating and development),

- $\quad$ creating an image of a newly formed group and deciding whether the group will be presented as a whole or the separate subjects will retain their individual identity

- developing marketing communication strategy in reference to the whole capital structure, it will also influence interpersonal and managerial communication in the group of companies,

- determining a new group of stakeholders and focusing on them the operations that create the image of the capital group,

- $\quad$ implementing a strategy of managing reputation and crisis common for the whole capital structure. 
Creating capital structure identity is not an easy task. Still, however, this issue is often a neglected one. Thus, understanding the importance of identity as a valuable asset of a capital structure or of an individual company plays a key role in its communication with the environment, and also in creating its image and reputation.

\section{AUTHOR INFORMATION}

Anna Zarębska. Master of Management (1998) and Ph.D in Economic Sciences (2001). A lecturer of the Department of Management at the Lublin University of Technology and at the Higher School of Business and Administration in Lublin. A lecturer in MBA (Lublin University of Technology - University of Illinois, USA) program. Program Director in the New Horizons ${ }^{\circledR}$ Company (since 2003). She is a co-author of the market success of this company. A certified coach of Lublin Investment Certification Programme concerning EU funds. She specialises in people and their personal development, communication, negotiation, HR management and professional customer service.

An author of books: Organizational changes - theory and practice (2002), Organizational identity. Creating a competitive company (2008), Identyfication of organizational identity in management of the company (2009). Coeditor of the book: Identity from a multi-layered perspective (2007). Author of many scientific papers (58) and restructuring projects for companies (25). Twelve-year training experience.

\section{REFERENCES}

1. Ashforth, B.E., Mael, F.A. (1996), Organizational identity and strategy as a context for the individual, "Advances in Strategic Management", Vol. 13.

2. Bandura, A. (1986), Social foundations of thought and action, Prentice-Hall, Englewood Cliffs, New York.

3. Barney, J.B., Hoskisson, R.E. (1990), Strategic groups: untested assertions and research proposals, "Management and Decision Economics", Vol. 11.

4. Bernstein, D. (1992), Company, image and reality. A critique of corporate communications, Cassell, London.

5. Blau, P.M. (1994), The structural context of opportunities, University of Chicago Press, Chicago, Illinois.

6. Caves, R.E. (2007), Multinational enterprise and economic analysis, Cambridge University Press, Cambridge.

7. Caves, R.E., Porter, M.C. (1977), From entry barriers to mobility barriers, Quarterly Journal of Economics, Vol. 91.

8. Clarke, L. (1997), Zarzadzanie zmiana, Gebethner\&S-ka, Warszawa.

9. Coleman, J. (1990), Foundations of social theory, Harvard University Press, Cambridge, MA.

10. Filipek, J. (2000), Jak efektywnie pokazać grupę - prezentacja tożsamości zależnej, http://www.Biz.Reporter.pl, 5 sierpnia

11. Hatch, M.J., Schultz, M. (red) (2004), Organizational identity, Oxford University Press, Oxford.

12. Hatten, K.J., Hatten, M.L. (1987), Strategic groups, asymmetrical mobility barriers and contestability, "Strategic Management Journal", Vol. 8 No. 4.

13. Hax, A.C., Majluf, N.C. (1991), The strategy concept and process, Prentice Hall, Englewood Cliffs, New York.

14. Huff, A.S. (1982), Industry influences on strategy reformulation, "Strategic Management Journal”, Vol. 3 No. 2.

15. Koźmiński, A.K., Piotrowski, W. (red.) (2007), Zarzadzanie: teoria i praktyka, Wydawnictwo Naukowe PWN, Warszawa.

16. Masłyk-Musiał, E. (red.) (2006), Praktyka organizacji w ruchu: strategie i kompetencje w zmianach, Oficyna Wydawnicza WSM, Warszawa.

17. Peteraf, M., Shanley, M. (1997), Getting to know you: a theory of strategic group identity, "Strategic Management Journal", Vol. 18, Summer Special Issue.

18. Reger, R.K., Huff, A.S. (1993), Strategic groups: a cognitive perspective, "Strategic Management Journal", Vol. 14 No. 2.

19. Ring, P.S., Van de Ven, A.H. (1992), Structuring cooperative relationships between organizations, "Strategic Management Journal", Vol. 13 No. 7. 
20. Sikorski, Cz. (2002), Zachowania ludzi w organizacjach, Wydawnictwo PWN, Warszawa.

21. Sitko, W., Zarębska, A. (2007), Zintegrowany model zarządzania tożsamościa organizacyjna w przedsiębiorstwie, „Organizacja i Kierowanie”, 1.

22. Spender, J.C. (1989), Industry recipes: the nature and source of managerial judgement, Basil Blackwell, Oxford, United Kingdom.

23. Wilczak, A. (2004), Analiza przedsiębiorstwa i jego otoczenia pod kątem budowania tożsamości organizacyjnej, „Problemy Zarządzania”, 2.

24. Wood, R. (2006), Metody rekrutacji i selekcji pracowników oparte na kompetencjach, Oficyna Ekonomiczna, Kraków.

25. Zarębska, A. (2008), Tożsamość organizacyjna przedsiębiorstwa. Jak stworzyć konkurencyjna firmę?, Difin, Warszawa.

26. Zarębska (2009), Identyfikacja tożsamości organizacyjnej w zarządzaniu przedsiębiorstwem, Difin, Warszawa.

\section{NOTES}


NOTES 